\title{
Brigadas do antifanatismo: a invenção da tolerância religiosa
}

\author{
Antifanaticism Brigades: the Invention of the Religious Tolerance
}

Marcos Antônio LOPES

Resumo: Focando a produção de obras ficcionais e textos filosóficos em perspectiva histórica, o artigo aborda uma série de aspectos relacionados ao complexo universo temático das disputas intelectuais contra o fanatismo religioso na Europa Moderna. O texto analisa o advento e evolução de um tema que - já bastante recorrente na obra de autores modernos como Montaigne e Jean Bodin - , eleva-se à categoria de eixo temático em muitas das reflexões de autores dos séculos XVII e XVIII. Acerca da verdadeira cruzada das ideias, que foi a luta contra o fanatismo religioso durante a Idade Clássica e o Século das Luzes, são examinadas algumas das ideias críticas de escritores como Swift, Montesquieu, Voltaire, Diderot e David Hume.

Palavras-chave: História e Literatura; Crenças Religiosas e Concepções Políticas; Intelectuais e Poder.

\begin{abstract}
Focusing the production of fictional works and philosophical texts in historical perspective, the article approaches a series of aspects related to a complexed thematic universe of the intellectual disputes against the religious fanaticisn in Modern Europe. The text analyzes the advent and evolution of a topic which - is quite well-known in the work of modern writers like Montaigne and Jean Bodin - goes to the category of thematic axis in plenty of reflections of writers from the 17th and 18th centuries. About the real crusade of ideas which was the struggle against the religious fanaticism during the Classical Age and the Enlightenment, some of the critical ideas of writers like Swift, Montesquieu, Voltaire, Diderot and David Hume.
\end{abstract}

Keywords: History and Literature; Religious Beliefs and Political Conceptions; Intellectuals and Power.

Todas as vilezas e crueldades cometidas entre nós por entusiastas e fanáticos foram praticadas sob um disfarce de religião e longas preces

(Swift).

[...] a devoção inflama um coração inclinado à ternura, e dirige ao cérebro espíritos animais que também o inflamam, e daqui procedem os êxtases e os arroubos (Montesquieu).

O que responder a um homem que lhe diz ser mais agradável obedecer a Deus do que aos homens e que, em consequência disso, está certo de alcançar o céu quando lhe cortam o pescoço? (Voltaire).

Em todos os tempos seitas religiosas, heresias e cismas foram consideradas perigosas, e encaradas como origem de facção e oposição às leis. A autoridade pública sempre se aplicou, de diversas formas, a estancar esses males por meio de doutrinação, legislação e processos penais, ou

\footnotetext{
- Professor Doutor - Departamento de Ciências Sociais da UEL e do Programa de Pós-Graduação em História da UEM - UEL - Univ. Estadual de Londrina - Rodovia Celso Garcia Cid, PR 445, CEP: 86051-980, Londrina, Paraná, Brasil. E-mail: $\underline{\text { malopes@uel.br }}$
} 
pelo uso e abuso da força, originando reações e sucessivas ondas de violência. Muitas vezes, a intenção era a de suprimir indivíduos ou comunidades supostamente desgarrados, por meio de castigo exemplar a heréticos obstinados. Em alusão às relações de poder que se constituem historicamente nas diferentes sociedades, Montaigne afirmou que "em geral, os homens gostam acima de tudo de propagar suas idéias e quando carecem dos meios habituais, juntam-lhes o mando, a força, o ferro e o fogo" (MONTAIGNE, 2000, p.325, vol.02). Muito pertinente a afirmação desse filósofo francês do século XVI, a julgar por uma enormidade de evidências históricas. De fato, em fenômenos históricos que duraram séculos - como as Cruzadas cristãs da Baixa Idade Média, a Inquisição, a Caça às Bruxas e as Guerras Religiosas -, muito sangue foi derramado em disputas complexas em que, muitas vezes, o sentido da aplicação da violência estava fora do alcance da compreensão dos próprios atores envolvidos.

Durante a Idade Média e ao longo da Época Moderna, seitas religiosas e facções políticas sempre foram vistas como elementos de subversão da ordem pública, mesmo quando se materializavam em comunidades geograficamente distantes e isoladas do centro do poder. No Dicionário Filosófico Voltaire sentenciou que toda seita, independentemente do gênero, sempre seria a união da dúvida e do erro. Nessa obra, Voltaire dá sequência à racionalidade própria dos fanáticos:

Aquilo que minha seita ensina é obscuro, bem o sei, diz um fanático; mas é em virtude dessa obscuridade que devemos acreditar na seita [...]. Minha seita é extravagante, então é divina; do contrário, como seria possível que fosse adotado por tantos povos aquilo que parece uma tal insanidade se aí não houvesse algo de divino? (VOLTAIRE, 1994, p.474).

Cabe lembrar que o adjetivo 'fanático' procede do latim (phanaticus), e possuiu originalmente o sentido de devoto que pertence ao templo e que é inspirado pelos deuses, segundo a definição do Dicionário Houaiss da língua portuguesa. Já o substantivo 'fanatismo' procede do francês (fanatisme) e passou a outros idiomas preservando e ampliando o sentido original latino. No Webster's New Pratical Dictionary, por exemplo, tem-se a seguinte definição para fanatismo: "Entusiasmo excessivo ou zelo injustificado acerca de qualquer assunto" (VÁRIOS AUTORES, 1951, p.237).

Para os monarcas, os legisladores e o clero, as facções religiosas tornavam impotentes as leis e originavam discórdias entre os súditos pertencentes a um mesmo corpo político que, por isso mesmo, todos deviam oferecer proteção e assistência mútua. Nos meados do século XVIII o historiador e filósofo escocês David Hume afirmava que o fanatismo religioso era o princípio mais cego, obstinado e ingovernável capaz de atuar sobre a natureza humana. Segundo ele, a ira do povo ignorante era algo temível, independentemente do motivo que a originasse. Para Hume, a ira 
popular descontrolada vinha quase sempre acompanhada das consequências mais perniciosas, principalmente quando resultava de princípios que repudiavam qualquer controle da razão ou da lei.

Os maiores críticos do fanatismo religioso na Época Moderna - Montaigne, Bayle, Swift, Montesquieu, Voltaire, Hume, Diderot - convergem na constatação de que a mente fanática se auto-concebe como agente de uma iluminação superior. Fanáticos em diferentes tempos se proclamaram instrumentos da revelação de um espírito divino, ou seja, de uma vontade sobrenatural. Se as suas ideias não são propriamente deste mundo, mas inspiradas por entes que supostamente conseguem ver além das meras circunstâncias humanas, a crença na pureza e na verdade incontestável de seus princípios atua como um poderoso combustível para impulsionar ações que requerem fervor e ímpeto sem limites. Mas, como afirmou Hume, um zelo exagerado por parte de amigos é capaz de provocar espírito semelhante nos antagonistas (Cf. HUME, 2004). Essa parece ter sido a história de todas as guerras em que as justificativas religiosas formaram a base ideológica de sustentação. O espírito de proselitismo, ou seja, o impulso irrefreável em promover conversões, aparece como uma espécie de doença epidêmica na história. Segundo Montesquieu, esse mal passou dos antigos egípcios e judeus aos cristãos e muçulmanos de seu tempo. A demência que nasce desse espírito progride impulsionado por um "eclipse total da razão humana". Ora, aquele que deseja que eu professe a sua crença morreria feliz se se visse forçado a professar a minha. Encarnando o espírito pacifista que seria uma marca entre os intelectuais do século XVIII, Montesquieu afirmou: "Confesso que as histórias andam cheias de guerras de religião, mas repare-se bem: não foi a multiplicidade de religiões que ocasionou estas guerras, mas o espírito de intolerância que animava aquela que se acreditava dominante" (MONTESQUIEU, 1960, p.160). Contrariando a avaliação de Montesquieu sobre a tolerância religiosa entre os egípcios, Voltaire dirá acerca das raríssimas virtudes que conseguiu encontrar nesse povo: “[...] aqueles que adoravam um boi nunca quiseram constranger a mudar de religião os que adoravam um macaco" (VOLTAIRE, 1994a, p.72).

Ora, o que são as guerras de religião, independentemente dos contextos históricos em que emergem? Fundamentalmente, as guerras de religião são a história de fanáticos em movimento, seres que se autoproclamam instrumentos da vontade de um deus, que é a chama sagrada que os ilumina e alimenta em meio às tormentas e às provações necessárias para a afirmação da verdadeira fé. Fanáticos de todos os tempos sempre possuíram uma capacidade especial para amplificar as próprias virtudes do espírito, como a imaginação criativa, por exemplo. Eles devem hipertrofiar os dados da realidade que interpretam, dotando-lhes de um colorido mágico, por meio de um notável poder de expressão de suas ideias, poder este acentuado pelos esforços corporativos de uma razão enlouquecida. Na segunda metade do século XVI, o ceticismo tão peculiar a 
Montaigne levou-o a se pronunciar nos seguintes termos, acerca das opiniões inabaláveis desses bandos de sectários: "É lamentável que a maior prova da verdade de alguma coisa esteja no número de pessoas que nela acreditam, quando nesse mesmo número se incluem tantos loucos e tão poucos sábios" (MONTAIGNE, 2000, p.325, vol.02). Como disse zombeteiramente o escritor irlandês Jonathan Swift em fins do século XVII, “As duas principais qualificações de um pregador fanático são a sua luz interior e a cabeça cheia de minhocas; e os dois destinos diferentes dos seus escritos são ou bem serem queimados ou bem comidos por vermes" (SWIFT, 1999, p.125). Entretanto, a história realmente demonstrou que ao menos um desses destinos se tornou realidade efetiva uma vez que os escritos de alguns pregadores foram realmente queimados, junto com os pregadores. De fato, a maior parte dos processos de heresia e bruxaria foi destruída, quando concluídos.

O autêntico fanático, o fanático 'exemplar', se assim se pode referir, é o indivíduo que não percebe limites para as suas ações rumo ao triunfo de sua fé. Ele orienta seu pensamento na escala da "ausência do sentido do impossível" (expressão de Lucien Febvre), como acreditar piamente naquilo que nunca viu e naquilo que ninguém nunca pôde provar. Exemplos dessa cegueira seletiva são os inquisidores espanhóis e portugueses descritos por Montesquieu, que aceitam testemunhos dos inimigos do acusado, de prostitutas e de ladrões (MONTESQUIEU, 1960, p.75); ou os membros do Parlamento de Bordeaux, "que perseguem alegremente aldeias inteiras denunciadas por um garoto de quatorze anos" (MANDROU, 1979, p.62); ou mesmo o bispo maníaco do século XIV, Jacques Fournier, estudado por E. Le Roy Ladurie, representante paradigmático "[...] das ambições de uma Igreja totalitária, exterminadora das diferenças de opinião" (LE ROY LADURIE, 1997, p.44). Tais casos parecem demonstrar que fanáticos fazem da religião uma eterna fonte de facções e dissidências internas e, por causa da religião, se matam mutuamente sem se importar tanto que, em meio às suas guerras santas, o seu próprio território esteja sendo invadido por exércitos estrangeiros. Com a visão bloqueada pelo dogma, não têm consciência de seus excessos. Em sua autorrepresentação, tomar-se-ão por figuras modelares da virtude. Tudo deve se submeter à ortodoxia. Em princípios do século XVIII Montesquieu zombava dos padres fanáticos de todas as ordens religiosas, que queriam incutir nos outros a própria opinião. Isso era algo como se os europeus, em favor do aperfeiçoamento da humanidade, quisessem branquear os africanos. Pontuando a hipocrisia e o casuísmo do clero católico, o autor dispara: "Alguém disse muito bem que, se os triângulos fizessem um deus, lhe dariam três lados" (MONTESQUIEU, 1960, p.119). Depositários da verdade, fanáticos pretendem possuir o monopólio do gozo da luz do sol — na expectativa de que exista sobre a terra apenas a sua religião —, privando dessa benção exclusiva todos os 'outros' crentes. 
Já no século XVI alguns homens de cultura percebiam as complicadas relações que o fanatismo religioso entretecia com a jurisprudência. Montaigne recomendava cautela contra a exagerada fantasia que pautava os processos de feitiçaria. Ele já reconhecia como excessivas as condenações à morte resultante desses obscuros processos. A regra que o filósofo recomendava aos juízes, quando diante de casos que não compreendiam, era: reconhecer com humildade a total ignorância e recomendar que as partes ali retornassem, decorridos cem anos. Esse filósofo cético narra a curiosa cena de um interrogatório, do qual participou como interpelador. Num grupo de uns doze acusados de feitiçaria estava "[...] uma velha que, pela sua feiura e sua deformidade (indício demoníaco), era uma verdadeira feiticeira". Ao ouvir a suposta energúmena, depois de examinar atenta e incredulamente as peças do processo, notou logo que se tratava de um caso incontestável de loucura, muito antes que de possessão diabólica. Teria recomendado um calmante à velha senhora, poupando-lhe da fogueira (MONTAIGNE, 2000, p.329, vol.02). Também Cervantes manifestou absoluta descrença na capacidade efetiva atribuída aos feiticeiros de seu tempo em praticar qualquer tipo de sortilégio. No Dom Quixote ele pondera, em um tom grave que contradiz o espírito hilário tão peculiar de sua escrita:

[...] sei muito bem não haver no mundo feitiços que possam mover e forçar as vontades, como cuidam alguns palermas; o alvedrio da pessoa é livre, e não há erva nem encanto que o obrigue. $\mathrm{O}$ que algumas mulherinhas tolas e alguns velhacos embusteiros costumam fazer são certas mistelas e venenos, com que tornam os homens doidos, dando a entender que são específicos para bem-querer, sendo, como digo, coisa impossível forçar-se a vontade de ninguém (CERVANTES, 1981, p.123).

Como sabemos, em seus transes de doida excentricidade, o Quixote também tem os seus lampejos de imprevisível juízo, que parecem traduzir a intenção de seu criador.

Os filósofos iluministas também foram pródigos em denunciar tartufos. No diálogo filosófico O Sobrinho de Rameau Diderot descreve a triste sina de um judeu traído por um pobre coitado a quem abrigara sob seu próprio teto, e que estava de olho em seu patrimônio: "O sublime em sua maldade está em ter sido o próprio delator de seu bom amigo israelita, aprisionado pela Santa Inquisição ao despertar, e que dias depois virou um belo fogo de artifício” (DIDEROT, 1973, p.367). Com efeito, no século XVIII os combates contra o fanatismo compõem um dos mais interessantes capítulos da história dos intelectuais. Na era do Iluminismo, Voltaire afirmou que seria mais fácil conduzir cem mil homens ao combate do que aplacar o espírito de um fanático movido por sua crença: “essas pessoas estão persuadidas de que o espírito santo que as penetra está acima das leis, e que seu entusiasmo é a única lei que devem escutar. O que responder a um homem que lhe diz ser mais agradável obedecer a Deus do que aos homens e que, em consequência disso, está certo de alcançar o céu quando lhe cortam o pescoço?" (VOLTAIRE, 
1994a, p.265). Para ele, as guerras religiosas eram, de longe, o tipo mais abominável de dissensão. As guerras de religião eram uma espécie de furor peculiar aos cristãos. Montesquieu pensava de modo semelhante, fazendo suas confissões sobre a fúria fanática dos cristãos por intermédio da ficção literária: “[...] posso assegurar-te que nunca houve reino em que tenha havido tantas guerras civis como o de Cristo" (MONTESQUIEU, 1960, p.74). Na perspectiva de Voltaire, são os membros dessa seita que asseveram: pensa como eu, ou Deus lhe condenará. E mais do que rapidamente já estão aos berros: pensa como eu, ou lhe matarei, como afirma no texto intitulado "Sur la superstition", reflexão que integra a obra vária reunida nas Mélanges (Cf. VOLTAIRE, 1961, p.1124). No artigo "Examen important de Milord Bolingbroke ou le tombeau du fanatisme", reunido na mesma obra, seu anticlericalismo o leva a indagar:

os homens são bem cegos e muito infelizes de escolher uma seita absurda, sanguinária, sustentada por carrascos e rodeada por estúpidos [...]. E qual rei, eu pergunto, qual magistrado, qual pai de família não preferirá ser senhor em sua casa a ser escravo de um padre? (VOLTAIRE, 1961, pp.1098s).

A obsessão com a heresia surgida dentro da Europa fez com que os católicos tivessem uma propensão a tolerar melhor os muçulmanos do que os luteranos e calvinistas, cristãos como eles mesmos. O traidor de dentro é pior que o inimigo exterior e urge arrancá-lo de seu esconderijo para eliminá-lo sem trégua nem piedade. Certamente, o fanatismo é a força motriz desse fenômeno que se estende, ao menos, até o final do século XVII. Numa obra literária Montesquieu refletiu que as divisões internas entre muçulmanos podiam levar a uma realidade semelhante. Nas Cartas Persas um de seus personagens centrais sugere que os cristãos, mesmo sendo infiéis, deveriam merecer um rigor menor em relação àqueles outros muçulmanos a quem os sagrados profetas do Islã passaram a espada. Os cristãos são comparados aos idólatras que viveram antes do advento do Profeta. Eram, portanto, bem menos perigosos que os desviantes da dogmática comum "porque, em matéria de religião, os parentes mais chegados são os mais implacáveis inimigos" (MONTESQUIEU, 1960, p.120).

A história para Voltaire, concebida como um longo cortejo das tragédias que sempre se abateram sobre o gênero humano, foi quase sempre a filha legítima do fanatismo. O Voltaire historiador, ao escrever a história dos homens, tem sempre a impressão de ter escrito a história de tigres e de serpentes. Mas não, nos diz ele em seu célebre Ensaio sobre os costumes, as feras não são capazes de injuriar tanto a própria espécie. No texto intitulado "Du protestantisme et de la guerre des Cévennes", trabalho que integra as Oeuvres historiques, o autor analisa um conflito entre católicos e protestantes ocorrido na França em 1704, o filósofo iluminista se impressiona com a onda de furor de parte a parte. Os dois partidos, logo assassinos e assassinados, invocavam igualmente o nome do senhor. Mais de quatro mil fanáticos pereceram nas rodas de tortura e nas 
fogueiras, sem que não houvesse um único que não abençoasse ao seu deus (VOLTAIRE, 1957, p.1280).

Exemplo notório do fanatismo descrito por Voltaite é a crença na existência real da bruxaria que, no século XVII, levava a arroubos de convicção como a do juiz francês Henry Boguet: "espero que entendam bem que sou inimigo figadal dos bruxos e que nunca os pouparei, tanto por suas abominações execráveis quanto por seu número infinito que aumenta a cada dia (Citado por SALLMANN, 2002, p.35). Na Idade Média e ao longo da Época Moderna, fanáticos enxergavam em qualquer manifestação social ou fenômeno da natureza - que não conseguiam compreender racionalmente -, os elementos que explicavam um castigo de Deus ou as perniciosas intervenções de práticas de magia. Assim é que guerras civis, crises econômicas, estiagens, epidemias e doenças dos rebanhos eram logo identificadas e confundidas com feitiçaria ou punições da Providência.

Na Baixa Idade Média e até os inícios do século XVIII em algumas regiões da Europa, o zelo religioso em torno aos dogmas daquilo que deveria ser a pureza da ortodoxia religiosa gerou numerosos e sangrentos conflitos. As Cruzadas Cristãs, bem como as Guerras de Religião entre católicos e protestantes, os processos de Caça às Bruxas e a perseguição aos hereges fustigados pelo Santo Ofício demonstram como a convicção e a imaginação em excesso, sobretudo no campo religioso, podem assumir a dimensão de um fervor irracional, obsessivo e incontrolável. A intolerância religiosa na Época Moderna foi um dos principais desdobramentos do fanatismo religioso, uma arma afiada sob o poder de facções guiadas por líderes supostamente inspirados. Assim foi com católicos e huguenotes na França do século XVI. Assim foi também com conservadores e puritanos na Inglaterra do século XVII, no tempo da guerra civil. O fanatismo religioso forma fileiras de perseguidores aguerridos, e as expressões de seus atos desdobram-se sob a forma de uma profunda devoção. Como disse Swift, "Cromwell e seus aliados foram à procura de Deus, como eles mesmos disseram, quando resolveram matar o rei” (SWIFT, 1999, p.253.).

Não se concebe o fanatismo religioso cristão da Idade Média e da Época Moderna sem um desenvolvido sentimento de auto-piedade e uma clara definição quanto a pureza da própria fé. A literatura crítica dos séculos XVII e XVIII, que promoveu uma poderosa cruzada contra o excesso de zelo religioso - com Pierre Bayle, Swift, Fontenelle, Voltaire e Diderot, para falar apenas de alguns autores mais conhecidos hoje - , colocou em evidência os temíveis efeitos do fanatismo sobre o caráter dos indivíduos. Acerca da autocomiseração de religiosos fanáticos, vale lembrar a crítica hilária de Jonathan Swift. Em seu conto intitulado "Uma história de um barril" ele nos descreve as aventuras de um desses superiores de ordens que se crê a própria encarnação das virtudes de Cristo: 
Postar-se-ia na esquina de uma rua e, dirigindo-se aos passantes, gritaria a um deles: Dê-me a honra, ó meu digno senhor, de me dar um forte murro no queixo, e a outros: por favor, prezado amigo, propicie-me a capricho um pontapé no traseiro; permitiria a madame que eu lhe rogue, das belas mãos de vossa senhoria, um sopapinho no ouvido? Pelo amor de Deus, nobre capitão, conceda às minhas pobres costas uma justa bordoada desta sua bengala. E quando, por solicitações assim tão ardorosas, já encontrara meios de obter um espancamento suficiente para lhe intumescer a fantasia e o lombo, ele voltaria para casa reconfortado em extremo, e cheio de terríveis narrações sobre o que havia sofrido pelo bem público. Vejam só esta pancada (dizia mostrando as costas desnudas), um pestífero janízaro ma deu hoje de manhã às sete horas, quando, com muito afã, eu estava expulsando o grande turco. E esta cabeça quebrada, meus vizinhos, bem merece um emplastro (SWIFT, 1999, pp.255s).

O personagem histórico retratado por Swift é João, representação literária de três irmãos inicialmente unidos por traços identitários comuns, mas cuja amizade fraterna se rompe quando um deles se arvora em líder religioso. Os trigêmeos Pedro, Martin e João viviam num perfeito clima de paz e amizade até que Pedro - que representa o papa — se autoproclamou senhor absoluto dos demais. Os acontecimentos que se seguem são uma alegoria cômica da história do cristianismo a partir da Reforma. Os irmãos que Pedro tenciona subjugar - Lutero e Calvino, respectivamente - , serão os fundadores de seitas que, opondo-se ao formalismo e ao fanatismo de Roma, ajudam a espalhar mais sangue e morte pelo mundo. O que Swift retrata como escritor, o que faz de sua obra um importante foco de fissura no processo global conhecido como a "crise da consciência europeia" - a emergência de uma forma crítica de análise da sociedade, que antecede e prepara o Iluminismo - é a devoção profunda a uma crença capaz de chegar ao extremo de o fanático oferecer o seu corpo à flagelação. $\mathrm{O}$ autor representa, por meio do cinismo e da ironia duas das principais virtudes que compõem o seu estilo - aquilo que distingue como os traços típicos de um fanático calvinista na Inglaterra do século XVII. Não basta a esses santarrões exibir publicamente o grau mais profundo de devoção à sua crença. É preciso destacar também a sua capacidade de sofrer na própria carne toda a dureza utilizada por seus inimigos. Naturalmente, ele encontrará meios de mostrar aos seus confrades o seu total devotamento.

Muitos autores demonstraram que o fenômeno do fanatismo religioso no Ocidente medieval e moderno se materializou no combate a crenças reais e imaginárias, bem como na defesa de uma ortodoxia que se presumia sofrer o ataque de forças exteriores e invasoras da comunidade cristã. $\mathrm{O}$ texto de Swift, acima citado, foi escrito tendo em perspectiva o problema do fanatismo, expresso pela intenção de demonstrar como o fanático pode agir para realçar toda a pureza de suas ações, iluminadas por um forte desejo de seguir o caminho de salvação traçado por sua crença. A história do fanatismo está cheia de cenas como a de clérigos e de príncipes contemplando piedosamente de suas janelas a chama sagrada que purifica as almas dos hereges e das bruxas nas fogueiras. Nesse sentido, o fanático impõe a si mesmo privações e provações que demonstrem de forma inequívoca 
a retidão de suas ações. Como alerta Swift, fanáticos religiosos sempre encontraram meios de propagandearem a sua condição de vítimas de perseguição. Além disso, tendem a dar amplitude exagerada aos menores percalços que encontram em seu caminho, vistos como grandes obstáculos ao triunfo de seu credo. Saltar uma pedra pode ganhar um tal relevo como se da transposição de uma montanha se tratasse.

O texto de Swift em referência — "Uma história de um tonel" — foi escrito no ano de 1696, num momento em que temas religiosos ainda provocavam muita confusão e discórdia, principalmente quando mesclados a questões políticas. É pertinente lembrar que, por esta época, religião e política são categorias reflexivas, e que é sempre muito difícil a tarefa de distinguir a real extensão de cada uma delas. No presente caso, o alvo do autor são as atitudes fanáticas dos calvinistas ingleses. Nos fins do século XVII, na Inglaterra, os longos conflitos entre a realeza e o Parlamento, ainda são referências muito presentes na memória coletiva da nação. Esse conto de Swift descreve as expressões do fanatismo religioso ao demonstrar como os chefes de ordens religiosas se apegam facilmente aos atavios que ornam a sua seita, importando-se muito menos com as implicações morais da crença que abraçou. Isso é o mesmo que dizer: o fanático, de um modo geral, se apega à liturgia, se ocupando bem menos com os dramas da fé, que o guiariam a viver a religião num espírito de devoção e de tolerância. $O$ ornamento ganhava uma dimensão excessiva. Assim, a importância dada à forma ultrapassava a relevância conferida ao conteúdo. Desse tema já havia se ocupado Erasmo de Roterdã, nos inícios do século XVI. Para o autor de $O$ elogio da loucura, as cores das vestes dos padres eram o que menos importava na celebração do culto de Cristo. A reação de Montesquieu demonstra que a tendência de sacrificar a fé em nome da liturgia ainda estava bem viva nos finais do século XVII. Pois foi com os primeiros desdobramentos da Revogação do Edito de Nantes — ato pelo qual os franceses perseguiram outros cristãos cujo único mal foi o de professar um credo um pouco diferente da dogmática de seu soberano - que "todos se convenceram de que é muito diferente o fervor de converter os que não crêem numa religião, da observância dos seus preceitos, e de que, para a observar e amar, não é necessário odiar nem perseguir aos que não a seguem” (MONTESQUIEU, 1960, p.120).

Homens de letras como Bayle, Swift e Voltaire fizeram a literatura assumir novas tarefas e responsabilidades. Fanaticamente antifanáticos, esses intelectuais transformaram a literatura em máquina de guerra, em um eficaz instrumento de intervenção política. No livro $A$ religiosa, de 1760, que narra as desventuras de uma jovem desgarrada da família, Diderot utilizou-se dessa nova máquina de guerra para denunciar a vida devassa que se vivia nos conventos e o ambiente autoritário e alienante que compunha e reproduzia uma mentalidade submissa aos ditames clericais (Cf. DIDEROT, 1980). A partir dos finais do século XVII - com Bayle e Swift, e principalmente com o advento do Iluminismo nos meados do XVIII —, a literatura tornou-se algo para muito além 
de simples diversão e instrução. Aqueles textos dirigidos especificamente contra as exacerbações do sentimento religioso tornaram-se uma poderosa espada, a partir de então manejada por escritores interessados em expor e analisar para um público cultivado os males causados pela superstição e pelo fanatismo. Na época do Iluminismo, a literatura transformou-se rapidamente numa força capaz de despertar e guiar uma nova consciência. Essa foi uma guinada que fez da literatura algo muito diferente daquilo que havia sido nas mãos hábeis e talentosas dos autores da era do absolutismo de direito divino. Boilleau-Despréaux, Bossuet e outros escritores da Idade Clássica haviam oferecido suas penas para servir aos interesses da religião e do príncipe, cujo exercício do poder, com tendências sectárias, promovia guerras movido pela cobiça e pela intolerância. Sem dúvida, o fanatismo religioso entra na composição do grande entusiasmo com que Bossuet aplaudiu a revogação do Edito de Nantes, ato de Luís XIV, em 1685. Esse episódio demonstra como, em fins do século XVII, as controvérsias religiosas ainda abrem vasto terreno para a poderosa ação da intolerância e da superstição. E também nesse caso a literatura atuou como autêntica máquina de guerra. Boileau situou o seu rei no centro de uma polêmica literária que fez dele o maior monarca de todos os tempos. Com efeito, a querela entre os antigos e os modernos, ao concluir pela superioridade destes últimos, acabou por legitimar as ações mais iníquas de Luís XIV. Os sermões e os livros de história e de política escritos por Bossuet talvez formem a mais fabulosa concentração de panegíricos que já se escreveu no século XVII sobre as virtudes superiores de um príncipe.

Assim é que a literatura do absolutismo, à sua maneira, também esteve engajada em lutas políticas, não se constituindo em incursões desinteressadas pelo universo do beletrismo. A diferença fundamental entre autores como Bossuet e Voltaire, por exemplo, está nos ideais que defenderam. Nesse terreno, contrastam a obediência passiva e a consciência crítica, a força da tradição e a rebeldia iconoclasta. O pensamento político do século XVIII transformou as justificativas ideológicas do absolutismo numa agressão tirânica contra as sociedades humanas. As defesas teológico-religiosas do poder político - expressas pela doutrina do direito divino dos reis - foram dissolvidas pelo novo exercício da razão crítica. Processos judiciais que se tornaram célebres, como o caso Calas, tiveram como combustível o fanatismo religioso tanto das pessoas comuns como dos juízes cultos. Face às atrocidades do fanatismo religioso, a razão iluminista iria se manifestar de maneira muito afirmativa, numa poderosa onda de sabotagem crítica contra a história sagrada de Bossuet, assim como contra os mitos políticos e outras formas de superstição. Uma considerável ruptura marcou a nova forma de encarar a história e as ações políticas. Para Bossuet, por exemplo, a revogação do Edito de Nantes foi um ato supremo do rei, em nome da preservação da verdadeira fé, e os huguenotes queimados por Francisco I em 1535, um exemplo de 
piedade cristã. Para Voltaire, esses foram dois atos movidos à base de insensatez e intolerância, frutos do fanatismo clerical, uma perniciosa influência para os príncipes.

No século XVIII o fanatismo religioso foi atacado com tanta virulência porque o identificaram como a principal origem do mal entre os homens. São os clérigos fanáticos que estão por trás de episódios como a Revogação do Edito de Nantes, a blasfemar contra a razão, a atentar contra a tolerância, fonte da paz, da estabilidade e da prosperidade de uma nação. A luta anticlerical ganhou ainda uma importante dimensão econômica. Padres e freiras são seres perniciosos aos interesses de um reino, afirmavam vigorosamente Montesquieu, Voltaire e Diderot. A reprovação do monarquismo como fonte de esterilização do bem mais precioso de uma nação — os homens - reflete-se nas seguintes palavras de Montesquieu: "Este ofício de guardar castidade deu cabo de mais homens que as pestes e as guerras mais cruentas" (MONTESQUIEU, 1960, p.207). Estes 'sorvedouros' de famílias, por onde grassam a superstição e o fanatismo, em poucas gerações arruinará o que poderia ser um próspero Estado, afirma Voltaire no conto filosófico intitulado "L'ingénu", trabalho ficcional que integra a coletânea Romans et contes.: "Não só perde ele de quinhentos a seiscentos mil súditos muito úteis, como os faz inimigos seus" (VOLTAIRE, 1994b, p.516). E Diderot fará coro a Voltaire. Tal como o autor do Candide havia feito no conto filosófico O ingênuo, de 1767, no Suplemento à viagem de Bougainville, diálogo filosófico escrito em 1772, mas publicado somente em 1796, Diderot põe em cena um aborígine do Taiti a dar lições de economia política a um clérigo francês: "Uma criança é um bem precioso, porque deve tornar-se um homem. [...] Uma criança que nasce ocasiona alegria doméstica e pública: é um acréscimo de fortuna para a cabana e para a nação" (DIDEROT, 1973, p.443).

A razão iluminista quis enfraquecer os vícios produzidos pelo fanatismo religioso sobretudo a mentira e a perseguição - acentuando o poder benéfico de virtudes como a verdade e a tolerância, como fez o próprio Voltaire. Os clérigos que inspiraram o fanatismo religioso em Luís XIV, que levou ao sectarismo e à consequente expulsão dos huguenotes em 1685, formam uma instituição estéril e onerosa à nação. Segundo Voltaire, o clero ceifa o reino de suas forças produtivas mais caras: os homens aptos às atividades rentáveis. Em seu conto filosófico História de Jenni ou o ateu e o sábio ficamos sabendo, por intermédio do filósofo, como raciocinava a mente clerical: "Este homem é judeu, precisa pois ser queimado; e todos os seus bens me pertencem" (VOLTAIRE, 1994b, p.537). Desfradar o mundo é fazer a obra civilizadora de extirpação do fanatismo da face da terra. E essa cruzada contra os frades será justificada pelo fato de que eles são criaturas hostis à sociedade, porque são cadáveres que precisam ser ressuscitados para a vida e o trabalho produtivo. Como veneno para a erradicação do fanatismo, seria preciso transformar abadias e conventos em hospitais, escolas e fábricas, nos diz Voltaire. Esse desejo foi expresso no romance filosófico "L'Homme aux quarente écus”. Desse modo, 
A pátria teria mais homens úteis e menos infelizes. [...]. Os monges são parricidas que aniquilam uma posteridade inteira. Noventa mil enclausurados, que berram ou fanhoseiam latim, poderiam dar, cada um, dois súditos ao Estado: o que soma cento e oitenta mil homens que eles fazem perecer ainda em germe. Ao cabo de cem anos, a perda é imensa, coisa que se demonstra por si mesma. [...]. Ora, é claro que, se todos os jovens de ambos os sexos se enclausurassem, o mundo pereceria; já só por isso, a fradaria é inimiga da natureza humana, independentemente dos terríveis males que algumas vezes lhe causou (VOLTAIRE, 1994b, pp.652ss).

Então, fica-se sabendo que, para o autor do Cândido, os partidários das seitas consentidas, ou mal toleradas, - o que fundamentalmente é quase a mesma coisa, dependendo apenas do estado de espírito dos príncipes - são criaturas muito úteis a uma nação. E sob este aspecto, muito mais até do que a maior parte daqueles que, nas sociedades aristocráticas do Antigo Regime, professavam a religião oficial. Ora, as minorias religiosas podiam distinguir-se apenas pelas riquezas que produziam com o suor do próprio rosto, por estarem afastadas dos cargos importantes, das dignidades e honrarias.

Voltaire foi um admirador confesso do humor sarcástico de Swift, a ponto de declarar que quanto mais lia as obras do escritor irlandês, mais se envergonhava das suas. Esse mesmo tema dos frades, abordados como parasitas de uma nação - que sem dúvida foi re-apropriado e desenvolvido por Voltaire —, aparece desde o início do século XVI, na obra de Thomas Morus, por exemplo. Na opinião do Chanceler de Henrique VIII, nobres e frades eram como "zangões ociosos", nutrindo-se do trabalho alheio. Dois séculos mais tarde Swift deu a esse assunto o texto "Um argumento contra a abolição do cristianismo" (Cf. SWIFT, 1999, pp.424ss). Como Pierre Bayle, Fontenelle e Swift, Voltaire também se engajou nas muitas lutas do bom senso contra a insensatez de clérigos e juízes do Antigo Regime. Ele se defrontou corajosamente com a poderosa Igreja do Antigo Regime e escolheu Dos delitos e das penas, obra do jurista e filósofo italiano Cesare Beccaria, como uma espécie de livro de cabeceira dos novos tempos de uma civilização liberta dos horrores do fanatismo. Escreveu para o livro de Beccaria um "Comentário", que foi publicado como prefácio, em muitas edições europeias do século XVIII, o que contribuiu para ampliar a difusão da obra do jurista milanês. Sua adesão às ideias de Beccaria é bem a marca de seu combate contra a "astrologia judiciária" — julgamentos que admitem a culpabilidade ou a inocência por meio de desígnios misteriosos, como a prova da água - , muito forte até o século XVII, mas ainda presente nos tribunais da Europa de seu tempo, e disposta a julgar e a punir sortilégios e possessões diabólicas, individuais e coletivas. Em seu livro Le Siècle de Louis XIV, Voltaire aplica a moral de uma fábula de La Fontaine como denúncia dos Parlamentos e dos juízes: “[...] perdoa-se tudo aos leões, aos lobos e aos ursos, e um animal inocente é sacrificado por ter comido um pouco de erva" (VOLTAIRE, 1957, p.1013). Isto é sintomático de que ele enxergava com horror as práticas de tortura largamente utilizadas em seu tempo, e se revoltava contra a 
desproporcionalidade entre crime e castigo. É um Voltaire tomado de irônica indignação pelo "caso La Barre" que ouvimos em O homem dos quarenta escudos, outro de seus numerosos contos filosóficos: "Podem outros pensar de modo diferente, e cada qual a seu gosto; mas já se disse, e cumpre repetir, que um enforcado não serve para coisa alguma, e que os castigos devem ser úteis. Há alguns anos, na Tartária, dois jovens foram condenados ao empalamento por terem assistido, de chapéu na cabeça, a uma procissão de lamas. O imperador da China, que é homem de muito espírito, disse que os teria condenado a marchar em procissão, sem chapéu, por três meses" (VOLTAIRE, 1994b, p.658). A crítica que Voltaire fez da justiça de seu tempo foi uma coordenada que a cultura política ocidental não mais perdeu de vista. Por que fazer perecer criaturas que, por pequenos deslizes da mocidade, são jungidas às rodas e até levadas à fogueira, como se tivessem executado hediondamente uma mãe, um pai, um irmão? No conto filosófico "La Princesse de Babylone", quem surge em cena é o Voltaire das lettres de cachet, o intelectual dos diversos refúgios, o homem caçado pelos gendarmes parisienses durante quase três décadas:

\begin{abstract}
Outros ocupados, em menor número, eram zeladores de antigas usanças bárbaras contra as quais bradava a natureza; não consultavam senão os seus registros roídos de traças. Se ali encontravam algum costume insensato e horrível, consideravam-no como uma lei sagrada. Devido a esse covarde hábito de não ousarem pensar por si mesmos, e de haurirem suas idéias nos destroços dos tempos em que não se pensava, é que, na cidade dos prazeres, ainda existiam costumes atrozes. É por esse motivo que não havia nenhuma proporção entre os delitos e as penas. Faziam às vezes um inocente sofrer mil mortes para obrigá-lo a confessar um crime que não havia cometido. Puniam uma leviandade de rapaz como teriam punido um envenenamento ou um parricídio (VOLTAIRE, 1994b, pp.602s).
\end{abstract}

O contraste nas intervenções críticas de autores como Swift e Voltaire — que marcam clara posição contra costumes incompatíveis com o estado da civilização europeia no século XVIII — é que, para combater a intolerância e o fanatismo, eles empregam armas semelhantes às de seus opositores. Com frequência, eles se revelaram fanaticamente antifanáticos e, em meio aos seus combates, usaram a intolerância contra a intolerância. Servir do próprio veneno, ou melhor, ir à casa do inimigo para abastecer-se de artilharia, eis a regra de ouro. Isso significa que, ao combater pela tolerância e contra o fanatismo, nem sempre é possível poupar-se inteiramente desse vício. Atacando com vigor o fanatismo religioso, alguns homens de letras da Época Moderna tentaram estabelecer um certo valor equitativo para todas as crenças. Partiam do princípio de que, se todas as religiões possuíam uma entidade suprema como objeto de sua adoração, por que essa ou aquela religião poderia se ter na condição de única crença portadora da pureza doutrinal e deter o monopólio da verdade? Para Voltaire, a superstição era irmã gêmea do fanatismo, arrastando os homens para um mundo de terror e confusão. Este autor conta que, todos os anos, no dia 24 de 
agosto, ele se sentia abatido e se deixava tomar por uma prostração incontrolável. Para Voltaire, os fanáticos da Noite de São Bartolomeu acreditaram na necessidade do banho de sangue como um dever de purificação; após todos aqueles atos de crueldade, que impressionaram o próprio inferno, acreditavam de boa-fé que Cristo e os santos ainda lhes ficavam devendo homenagens. Como afirmou no Dicionário Filosófico, "o mais detestável exemplo de fanatismo foi aquele dos burgueses de Paris, que se apressaram a assassinar, a degolar, a atirar pelas janelas, a esquartejar seus concidadãos na noite de São Bartolomeu, apenas porque não iam à missa" (VOLTAIRE, 1994a, p.264).

As ondas sucessivas de fanatismo que varreram a Europa cristã desde a Baixa Idade Média até os meados do século XVIII só podem ser explicadas quando se toma em perspectiva numerosos e complexos fenômenos históricos: as Cruzadas à Terra Santa, as Guerras de Reconquista na Espanha, os combates à heresia por parte do Santo Ofício, os processos de Caça às Bruxas e os conflitos das Guerras de Religião. É bom ressaltar uma vez mais que tais assuntos não são novidades recém-descobertas pelos historiadores. São temas clássicos da cultura intelectual do Ocidente e mereceram inúmeras abordagens nos campos da ficção literária, da historiografia, da antropologia. O cinema também tem transformado esses temas - aparentemente remotos e ultrapassados - em questões candentes para a reflexão de nosso tempo presente. Filmes como $O$ nome da rosa, Giordano Bruno, a Rainha Margot, dentre tantas obras de arte, são excelentes instrumentos de reflexão sobre temas que ainda hoje abalam o mundo. As confluências entre a religião e a política, a intolerância para com a diferença e o sentimento de superioridade cultural, eis temas que nos revelam os elos históricos de nossa aldeia global com as sociedades multifacetadas da Idade Média e as dos séculos XVI, XVII e XVIII. Expressões do fanatismo religioso - as Cruzadas, a Inquisição, as Guerras de Religião e a Caça às Bruxas — possuem como traço comum a tendência da autoridade religiosa, do poder político, e de seus agentes, de se contraporem às ideias de indivíduos ou grupos cuja crença foi percebida como diferente e, por isso mesmo, um mal em si. Fanáticos da Idade Média e da Época Moderna não se detiveram nem mesmo diante dos segredos de consciência, isto é, do que compreendemos hoje como tolerância e liberdade religiosa. Para eles, era preciso travar combates em defesa de um núcleo duro de crenças oficiais, de uma ortodoxia supostamente em perigo, que julga sem compreender e pune com sentenças pré-definidas. Como diria Montaigne, a razão humana é - e continua a ser — um “instrumento vago e mal regulado" (MONTAIGNE, 2000, p.324).

Por último, é preciso dizer que autores como Montaigne, Swift, Montesquieu, Voltaire, são praticamente inesgotáveis, em termos das possibilidades interpretativas sobre o fanatismo religioso. Séculos após sua concepção, suas obras continuam tendo algo de muito relevante a dizer e podemos compreendê-las segundo o padrão de nossas próprias experiências religiosas. Se de fato 
o que caracteriza uma obra clássica é a multiplicidade de sentidos e a inesgotabilidade de interpretações que permitem, em diferentes contextos de sua recepção, com toda certeza essas obras são clássicas, naquele sentido que atribuiu Italo Calvino, o de que um clássico é um livro que nunca terminou de dizer aquilo que tinha para dizer (Cf. CALVINO, 1993, p.11). Sempre será relevante a tentativa de compreender o sentido original que - em seu contexto social, histórico e cultural - tais autores atribuíram ao fanatismo religioso. Sem dúvida, a luta contra o fanatismo foi uma espécie de cruzada em que esses homens de letras participaram como aguerridos combatentes, na tentativa de extirpar um grande mal da face da terra. Mas, tão relevante quanto a tentativa de determinação do sentido de tais obras examinadas em seu lugar de elaboração é o esforço intelectual de apreender a significação que elas possuem acerca de tal tema para nós hoje, haja vista a presença ainda marcante do fanatismo religioso em nosso tempo.

\section{Referências bibliográficas}

CALVINO, Italo. Por que ler os clássicos. São Paulo: Companhia das Letras, 1993.

CERVANTES, Miguel de. Dom Quixote de la Mancha. São Paulo: Abril Cultural, 1981.

DIDEROT, Denis. A religiosa. São Paulo: Abril Cultural, 1980.

. Os Pensadores. São Paulo: Abril Cultural, 1973.

FEBVRE, Lucien. Le problème de l'incroyance au XVIe siècle. La religion de Rabelais. Paris: Albin Michel, 1948.

HUME, David. Ensaios morais, políticos e literários. Rio de Janeiro: Topboks, 2004.

LE ROY LADURIE, Emmanuel. Montaillou, povoado occitânico. São Paulo: Companhia das Letras, 1997.

MANDROU, Robert. Magistrados e feiticeiros na França do século XVII. São Paulo: Perspectiva, 1979.

MONTAIGNE, Michel de. Ensaios. São Paulo: Nova Cultural, 2000. (Volume 02).

MONTESQUIEU. Cartas Persas. Belo Horizonte: Itatiaia, 1960.

SALLMANN, Jean.-Michel. As bruxas noivas de Satã. Rio de Janeiro: Objetiva, 2002.

SWIFT, Jonathan. Panfletos satíricos. Rio de Janeiro: Topbooks, 1999.

VÁRIOS AUTORES. Webster's New Pratical Dictionary. Cambridge: Massachussets, 1951.

VOLTAIRE. Oeuvres historiques. Paris: Gallimard, 1957. (Organização: René Pomeau). . Mélanges. Paris: Gallimard, 1961. 
. Dictionnaire Philosophique. Paris: Gallimard, 1994a. (Organização: Jaques van den Heuvel).

Romans et contes. Paris: Librairie Générale Française, 1994b. (Organização: Edouard Guitton).

Artigo recebido em 03/2010. Aprovado em 05/2010. 